\title{
Vegetarian nutrition and healthy life
}

\author{
Nevin Sevmiş̧ ${ }^{1}$, Funda İfakat Tengiz ${ }^{2}$ \\ ${ }^{1}$ Izmir Katip Çelebi University Faculty of Medicine, Izmir, Turkey \\ ${ }^{2}$ Department of Medical Education, Izmir Katip Çelebi University Faculty of Medicine, Izmir, Turkey
}

\begin{abstract}
This review aims to examine the positive, and if so, the negative effects of vegetarian nutrition in humans. In addition, it also aims to determine the positive and negative effects of vegetarianism on chronic diseases, discuss how vegetarianism works, who should be considered vegetarian, and dietary diversity of vegetarian nutrition. Vegetarianism is briefly defined as the practice of abstaining from the consumption of meat (poultry, fish, cow, sheep, and other animals) for various reasons. Vegetarians consume other animal products, however, they prefer also them with a minimalizing way of thinking. Vegetarians may have various reasons for this practice, for instance, considering that the life of animals should not be a means of human life, or that human life can be sustained without consuming meat, etc. In brief, this study aims to clarify vegetarian nutrition, which is not exactly known to be, or which is known wrong by society.

Keywords: Chronic diseases, health, nutrition, vegetarian, vegetarian nutrition, vegetarianism.
\end{abstract}

According to the World Health Organization, health is "a state of complete physical, mental and social well-being and not merely the absence of disease or infirmity". ${ }^{[1]}$

Nutrition is the process of an organism consuming nutrients in order to grow, sustain life and maintain health. ${ }^{[2]}$

Vegetarianism is a form of nutrition in which foods of plant origin are preferred rather than foods of animal origin. ${ }^{[2]}$ Vegetarians are individuals who consume vegetarian foods in their meals and who consume little to no animal products (red meat, white meat, fish, dairy products, eggs, or honey). ${ }^{[2]}$

One study compared vegetarians and people with homogeneous diets and found that despite vegetarians weighing considerably less than non-vegetarians, the vegetarian diet provided significantly more energy compared to the homogeneous diet. ${ }^{[3]}$
Plants are a staple of the vegetarian diet. However, the vegetarian diet has many forms varying according to the degree of consumption of animal products. ${ }^{[4]}$ Among these are: lacto-ovo vegetarianism, lacto vegetarianism, ovo vegetarianism, pescatarian diet, semi-vegetarianism, pollotarian, fruitarians or frutist, rawist, macrobiotic, and vegan diets. ${ }^{[2,5]}$

Lacto-ovo vegetarian diet: This diet consists of vegetarian foods, egg, dairy, and dairy products ${ }^{[2,8]}$ and is currently the most commonly practiced vegetarian diet..$^{[5,6]}$ This diet is also compatible with the religious laws of Buddhism and Jainism. ${ }^{[5-7]}$

Lacto-vegetarian diet: This diet consists of vegetarian foods and also includes honey, dairy products (half and skim), but does not include meat, egg, or fish. ${ }^{[2,5-8]}$

Ovo vegetarian diet: Consists of vegetarian foods and eggs, while meat or dairy products are not consumed..$^{[2,5-7]}$ 
Pescatarian diet: This diet also includes fish, dairy products, and egg. ${ }^{[2,7]}$ Red and white meat are not consumed; however, this diet is not accepted as a vegetarian diet by the Vegetarian Society (The Vegetarian Society of the United Kingdom) since it includes fish. ${ }^{[8]}$

Semi-vegetarian diet (flexitarian): This diet includes egg, dairy products, and a limited amount of white meat (poultry) and fish ${ }^{[2,5,8]}$ and lies somewhere between the vegetarian and meatbased diet. ${ }^{[7,8]}$ It is not accepted as a vegetarian diet by the Vegetarian Society. ${ }^{[1]}$

Pollotarian diet: People who follow this diet consume vegetarian foods and sometimes poultry. ${ }^{[2]}$ This diet is also not accepted as a vegetarian diet by the Vegetarian Society. ${ }^{[8]}$

Vegan diet: This diet group does not consume any animal products (red meat, white meat, dairy products, honey, seafood, gelatin) and vegans also do not wear clothing obtained from animals (wool, silk, leather), soaps made from animal products, do not use products tested on animals (cosmetics, toothpaste, etc.), or visit circuses, etc. ${ }^{[2,5,7,8]}$ Currently, there is only a small number of vegans. Veganism also has subgroups..$^{[5,6]}$

Fruitarians or Fruitists: Those who follow this diet only consume fruits and vegetables and believe in the continuation of the life cycle. ${ }^{[2,5]}$

Rawists: Rawists believe that foods should not be cooked and that cooking food causes them to lose health benefits. ${ }^{[5]}$

Macrobiotic diet: This diet is generally not included among main diets. It includes granular foods whole grain products, and rarely seafood. ${ }^{[2,3]}$ This diet is low-energy. ${ }^{[3]}$

\section{THE EMERGENCE AND DEVELOPMENT OF VEGETARIANISM}

The first known origin of vegetarianism is unclear. $^{[8]}$ However, the emergence of vegetarianism may show parallelism with the start of human history. ${ }^{[4]}$ Vegetarianism emerged through the beliefs that killing animals is unethical or immoral, that the meat of killed animals was unclean, and that this meat would harm human health. ${ }^{[6]}$

Throughout history, many people (such as Empedocles claiming it was a virtue to not kill other living beings in $5^{\text {th }}$ century $\mathrm{BC}$, the teaching of metempsychosis by the Greek philosopher and mathematician Pythagoras, Leonardo da Vinci in the Renaissance, and Rousseau, Voltaire, and Tryon in the Age of Enlightenment) have contributed positive notions towards the development of vegetarianism. ${ }^{[2,8]}$ As vegetarianism advanced, vegetarian associations were established, and communities emerged. ${ }^{[2]}$

Religion has also had an effect on the development of vegetarianism. For instance, in the religions of Buddhism and Jainism, the killing and consumption of animals is prohibited due to the belief that "all life is sacred".

Those who defend vegetarianism believe that animal sources (such as cow's milk, chicken's eggs) could feed more people longer than animal meat. ${ }^{[6]}$ In short, many factors such as ecological and economic reasons, ethnic and religious beliefs, lifestyles, politics, animal welfare, health, interest in eastern philosophies, and environmental damage have been effective in the advancement of vegetarianism. ${ }^{[2]}$

\section{THE EFFECT OF VEGETARIAN NUTRITION ON DISEASES}

It has been stated that regular practice of vegetarian diet will allow more healthier individuals compared to normal diet, and prevent chronic illness. However, as in all diets, if vegetarian diet is not properly applied, it will have the opposite effect on health and cause metabolic disorders, vitamin deficiencies, and malnutrition (especially in vegans). ${ }^{[2,7]}$

According to Karabudak, ${ }^{[5]}$ not all forms of vegetarian nutrition are healthy, and there is a balance to everything. If vegetarians do not apply an orderly diet, many diseases are inevitable. For example,

- Lack of nutrition variety causes iron deficiency and anemia in vegetarians

- Vitamin B12 deficiency may occur, causing anemia and irreversible harm to the nervous system. B12 deficiency may progress and cause increase in homocysteine, which leads to increased rates of cardiovascular disease.

- Lack of calcium or insufficient intake may lead to bone diseases ${ }^{[5]}$ 


\section{CARDIOVASCULAR DISEASE (CVD)}

Cardiovascular diseases are responsible for $46 \%$ of deaths related to non-infective disease. ${ }^{[9]}$ Reduced saturated fat, cholesterol, and total fat in vegetarian diets, and the inclusion of tocopherols, dregs, arginine, and magnesium in these diets as well as hazelnuts, peanuts, and walnuts reduce the risk of developing these diseases. ${ }^{[5,6]}$

Ischemic heart disease: According to the results of large cohort studies and meta-analyses, vegetarians (lacto-ovo vegetarians and vegans) were found to have lower rates of mortality related to ischemic heart disease compared to individuals on a normal diet. ${ }^{[10]}$ Vegetarians were found to have lower body mass index compared to non-vegetarians, which lowers the risk of contracting heart disease..$^{[1,5,10]}$

\section{HYPERTENSION}

Vegetarians also have lower blood pressure and lower risk of hypertension compared to nonvegetarians. ${ }^{[5,6]}$ This is because the vegetarian diet contains less total fat, saturated fat, and cholesterol, while containing an abundance of plant-based products such as dregs, fruits, vegetables, and legumes and being rich in potassium, magnesium, and calcium and containing low amount of salt. ${ }^{[5,6]}$

A recent meta-analysis reported that there was a relationship between vegetarian diet and low blood pressure and that vegetarian diet may have a non-pharmacologic beneficial effect. ${ }^{[10]}$

Another recent meta-analysis of randomized clinical trials and observational studies indicated that plant-based nutrition had a positive impact on blood pressure..$^{[9]}$

\section{CANCER}

Vegetarians have a lower risk of developing cancer compared to non-vegetarians. ${ }^{[5,6]}$ The results of one recent meta-analysis found that vegetarians had $18 \%$ less cancer risk compared to non-vegetarians. ${ }^{[10]}$ However, this situation varies from cancer to cancer. ${ }^{[6]}$

According to the data from the Adventist Health Study, in people matched according to age, gender, and smoking, non-vegetarians had increased risk of developing colorectal and prostate cancer compared to vegetarians, while there was no difference in risk in lung cancer, breast cancer, stomach cancer, and uterus cancer. ${ }^{[10]}$

Vegetarian diet consists of increased consumption of walnuts, hazelnuts, legumes, vegetables, fruits, and grain products which increase the intake of antioxidants (vitamin $\mathrm{E}$, vitamin $\mathrm{C}$, carotenoids, etc.) therefore providing protection against cancer. ${ }^{[5]}$ However, some studies also indicate that consumption of fruits and vegetables have a protective effect against certain cancers, while having neither positive nor negative effect on other cancers. ${ }^{[10]}$

\section{OSTEOPOROSIS}

Decrease in minerals in bones cause bones to become brittle. ${ }^{[5,6]}$ Mineral loss in the body occurs independently from calcium intake, therefore osteoporosis risk is calculated according to calcium intake. ${ }^{[6]}$

Individuals who consume meat have higher osteoporosis risk, since meat contains protein and increased protein intake causes calcium loss and increases the excretion of calcium through urine..$^{[5,10]}$ When vegetarians consume enough low-fat milk and dairy products, green leafy vegetables, and some grain cereals, they receive sufficient calcium. This indicates that vegetarians have a lower risk of osteoporosis than nonvegetarians. ${ }^{[5,10]}$

\section{DIABETES MELLITUS}

High-fiber diets reduce the risk of diabetes compared to low-fiber diets. ${ }^{[5,6]}$ Studies on this subject have indicated that high fiber generally ensures glycemic control. ${ }^{[6,10]}$ As the vegetarian diet is rich in fiber, it could be said that vegetarians are at lower risk of diabetes compared to nonvegetarians. ${ }^{[5,6,10]}$

\section{OBESITY}

In a study consisting of 37,875 participants, non-vegetarians of the same age were found to have the highest body mass index, and vegans had the lowest body mass index, and other vegetarian groups were found to be in-between. The reason vegetarians have lower body mass index is because their diets consist of high-fiber and low-energy nutrients. ${ }^{[10]}$ This indicates that 
vegetarians (especially vegans) are at lower risk of developing obesity. ${ }^{[10]}$

In conclusion, vegetarian nutrition is a form of nutrition and a choice that people make according to their own thoughts, beliefs, cultures, and lifestyles. It could be concluded that proper food intake in vegetarian nutrition, as in all forms of nutrition, can have positive effects on diseases and may even be healthier than a normal diet.

\section{Declaration of conflicting interests}

The authors declared no conflicts of interest with respect to the authorship and/or publication of this article.

\section{Funding}

The authors received no financial support for the research and/or authorship of this article.

\section{REFERENCES}

1. Son T, Yasemin G. Biyoetik Çerçevesinde Vegan ve Vejetaryenlik [Doktora Tezi], Ankara: Ankara Üniversitesi Sosyal Bilimleri Enstitüsü Sosyal Çevre Bilimleri Anabilim Dalı; 2016.

2. Özcan T, Baysal S. Vejetaryen beslenme ve sağllk üzerine etkileri. Uludag Üniv Ziraat Fak Derg 2016;30:101-16.

3. Demir H, Ceyla SS. Vejetaryen enerji alımı. İnsan ve Toplum Bilimleri Araştırmaları Dergisi 2017;6:3193-20.

4. Segovia-Siapco G, Sabaté J. Health and sustainability outcomes of vegetarian dietary patterns: a revisit of the EPIC-Oxford and the Adventist Health Study-2 cohorts. Eur J Clin Nutr 2019;72:60-70.

5. Karabudak E. Vejetaryen beslenmesi. T.C. Sağllk Bakanlığı, Türkiye Halk Sağlığı Kurumu, Obezite Diyabet ve Metabolik Hastalıklar Dairesi Başkanlığı 2012;726.

6. Baysal A. Vejeteryan Beslenmesi: Beslenme ve sağllk yönünden değerlendirme. $\mathrm{J}$ Nutr and Diet 1995;24:181-94.

7. Yasemin Tunçay G. Sağlık Yönüyle Vegan\ Vejetaryenlik. Eurasian JHS 2018;1:25-9.

8. Yasemin Tunçay Son G, Bulut M. Yaşam tarzı olarak vegan ve vejetaryenlik. İnsan Bilimleri Dergisi 2016;13:830-43,.

9. Kahleova H, Levin S, Barnard ND. Vegetarian Dietary Patterns and Cardiovascular Disease. Prog Cardiovasc Dis 2018;61:54-61.

10. Akbulut G, editör. Diyetisyenlere ve Sağllk Profesyonellerine Yönelik Tibbi Beslenme Tedavisinde Güncel Uygulamalar 2 Vejetaryen Beslenmesi. Ankara: Nobel Tip Kitapevleri; 2016. 